\title{
Chromosome 15
}

National Cancer Institute

\section{Source}

National Cancer Institute. Chromosome 15. NCI Thesaurus. Code C13210.

The designation for each member of the fifteenth largest human autosomal

chromosome pair. Chromosome 15 spans about 106 million base pairs and represents between 3 and $3.5 \%$ of the total DNA in normal diploid cells. 